\title{
ライフライン地震被害に対する復旧過程の マルチェージェントシミュレーションの開発
}

\author{
堀 宗朗 $^{1}$ ・ 弓削田 恭兵 $^{2}$ ・市村 強 $^{3} \cdot$ Lalith WIJARTHNE $^{4}$ \\ 1 正会員 東京大学地震研究所 教授（＝113-0032 東京都文京区弥生 1-1-1） \\ E-mail: hori@eri.u-tokyo.ac.jp \\ 2 学生会員 東京大学地震研究所 大学院生 ( $\bar{T} 113-0032$ 東京都文京区弥生 1-1-1) \\ E-mail: yugeta@eri.u-tokyo.ac.jp \\ 3正会員 東京大学地震研究所 准教授 ( ⿳ 厂 113-0032 東京都文京区弥生 1-1-1) \\ E-mail: ichimura@eri.u-tokyo.ac.jp \\ 4 正会員 東京大学大学院工学系研究科 特任助教 ( $\bar{T} 113-8656$ 東京都文京区本郷 7-3-1) \\ E-mail: lalith@eri.u-tokyo.ac.jp
}

\begin{abstract}
本論文は, ライフラインの地震被害復旧の戦略立案支援を最終的な目的に, 復旧過程を模擬するマルチエー ジェントシミュレーション（Multi-Agent Simulation, MAS）の開発を試みる. 復旧過程を離散的な資材配分 問題として定式化し，この数理問題を解く数值解析手法としてMAS を設計する. 開発された MAS は，ライフ ラインの修復と利用をする技術者と使用者のエージェントから構成され, 多種多様のライフラインと技術者と 使用者を扱えるよう，オブジェクト指向プログラミングが活用されている. ライフラインのモデルの自動構築 も組み込まれている. 簡単な資材配分問題を使って開発された MAS の妥当性を検証し, ケーススタディを行い MAS の潜在的有効性を議論した.
\end{abstract}

Key Words : multi-agent simulation, earthquake recovery process, resource allocation problem, objectoriented programming, maximization of benefit

\section{1. はじめに}

1978 年宮城県沖地震を契機として，エネルギー・情 報・上下水道などのライフラインの地震被害に注目が

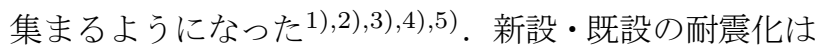
進んでいるものの, 総延長の長いライフラインでは大 地震による被害が根絶させられることは期待しづらい. ライフラインに被害が生じた場合を想定した合理的な 復旧が必要である ${ }^{6)}$ 。現時点では，供給開始までの時間 の短縮を目標に，被害個所をできるだけ一様に復旧す る戦略の下, 修復作業が行われている7)。 また, 修復作 業は個々のライフラインの事業者に委齐らている. ラ イフラインの使用者にとって現時点の復旧戦略は必ず しも最適ではなく，異なるライフラインの復旧の協調 も望まれる。しかしながら，使用者の便益を考えたり 復旧の協調をとることは決して容易ではない，使用者 やライフラインの種類が多いこと, さらには修復作業 そのものが複雑なことが原因である.

復旧戦略の高度化を念頭に, 使用者の便益や復旧の 協調を扱えるような，復旧過程の解析手法が必要であ る. 社会・経済のシミュレーションとして利用されてい るマルチェージェントシミュレーション (Multi-Agent Simulation, MAS $)^{8}$ は解析手法の候補である. MAS は, エンバイロンメントと称する社会のモデルの中を，人
や組織のモデルであるエージェントが自律的に動くシ ミュレーションである ${ }^{9), 10) .}$

上記を背景に, 本論文では, ライフラインの復旧過 程の MAS の開発を行う。エンバイロンメントはライフ ライン, エージェントはライフラインの修復と利用を 行う技術者と使用者である. 図-1 に MAS の概要を示 す．被害を受けた 4 つのライフラインが，右下の $2 つ$, 左上の 2 つの順で復旧する。 この過程は，2つの技術者 エージェントの修復で行われ，4つの使用者エージェン 卜が復旧に応じて利用を再開する。修復と利用の結果, ライフラインの損傷の低下と使用者の便益の回復が計 算される.

本論文の特徵は, 対象となる復旧過程を数理問題と して設定し, その数值解析手法としてMAS を設計する 点である. 複雑な修復作業を正確に定式化するには限界 があるため単純化は不可避であるが，数理問題の設定を 厳密にすることで, MAS の結果の曖昧性を無くすこと を試みる. 実際のライフラインのモデルと, いろいろな 技術者・使用者のモデルも必要となる. このため, 地理 情報システム (Geographic Information System, GIS) を使ったエンバイロンメントの自動構築と, 多種多様 なエージェントを扱うためのオブジェクト指向プログ ラミングの活用を行う。 

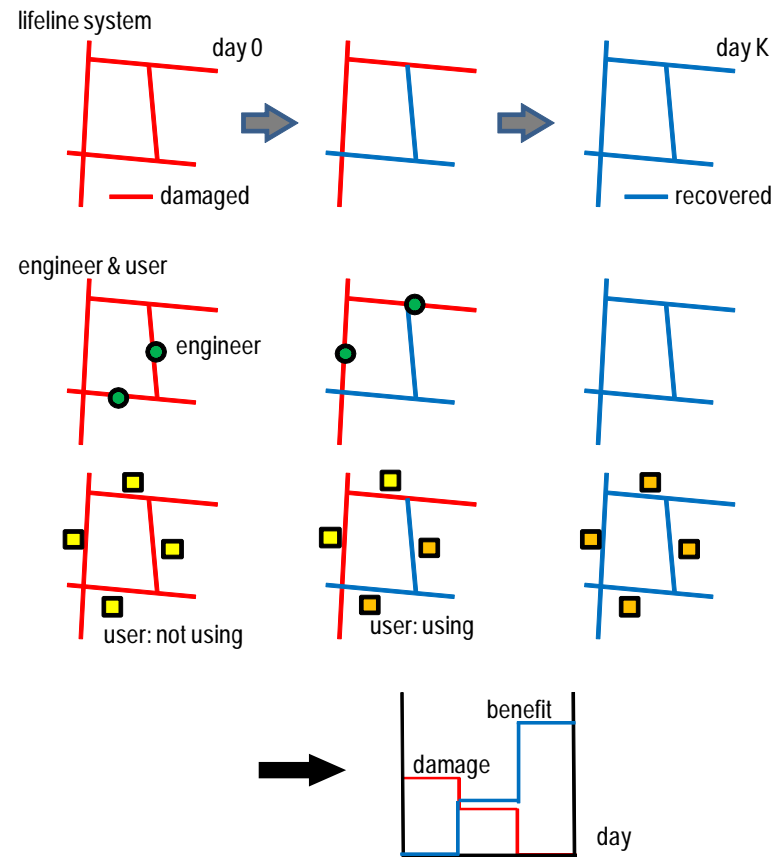

図-1 復旧過程の MAS の概要

本論文の構成は以下の通りである。第 2 章において ライフラインの地震被害の復旧と復旧シミュレーショ ンに関する文献調查を行う。第 3 章において復旧過程 に対し数理問題を設定する. 第 4 章ではこの数理問題 を解く数值解析手法として MAS を設計する. 第 5 章 において開発された MAS の性能を調べる．小規模な復 旧過程の解析解との比較から妥当性を検証し，大規模 な復旧過程の数值実験を行うことで有効性を議論する. この結果を基に，第 6 章において MAS の高度化の方針 を検討する。

\section{2. 既往研究の調査}

使用者の便益という観点が MAS に加わるため，最初 にライフラインの地震被害の経済評価を行った事例研 究を挙げる．梶谷ら ${ }^{11), 12)}$ は，ライフラインの産業活動 への重要度を示すライフライン途絶抵抗係数を産業業 種ごとに設定した。白谷ら ${ }^{13)}$ と土屋ら ${ }^{14)}$ は，ライフラ インの機能損傷が地域に与える経済的影響をマクロ的 に推計するための評価モデルを考案した。このような 研究は被害の経済評価が主眼であり, 復旧過程や経済 的観点からの復旧戦略最適化は考慮されていない.

ライフラインの地震被害に関する相互影響を分析す る研究事例もある。例えば，豊田・庄司15)が行った，複 数のライフラインを対象とした地震時応急復旧活動の 事例研究が挙げられる.これは, 電力やガスなど 6 種の ライフライン事業者が作成した首都直下地震発生直後 72 時間までのシナリオを基に, 復旧過程の間に生じ得
土木学会論文集A1 (構造·地震工学), Vol. 67, No. 1, 165-176, 2011

る事業者間の競合や支障等を定性的に分析したもので ある。白谷ら ${ }^{13)}$ は，大規模地震に着目した重要インフ ラの相互依存性解析より, ライフラインの相互連関を 前提とした防災計画や被害想定の必要性や，個々のラ イフラインの防災対策に関して提言を行っている。な お，ライフラインの相互依存性は都市の規模に応じて 指数関数的に複雑になるため, 依存性そのものの解明 や依存性に基づく地震被害の波及を評価するための研 究が進められいる19),20)。

次にライフラインの復旧戦略の研究を挙げる. ガス に関しては, 復旧戦略が公開されている77)。被災程度を 基に，復旧に必要な人的・物的資材の量を推定し，被災 個所を適当にブロック化し，各ブロックを一様に復旧 させるものである。電力に関して，佐賀井・朱牟田 17$)$ により復旧シミュレーションの開発が進められている. これは，災害時の配電設備被害への応急復旧過程を模 擬し，復旧の迅速化に関寸る試験的検討を行ったもの である.上水道に関しても復旧シミュレーション18)が 開発されている。これは，上水道管路網の被害予測結 果を基に，管路被害を効率的に応急復旧するための人 員配置等を訓練・習得するためのソフトウエアである.

既存のライフラインの復旧シミュレーションはオペ レーションズリサーチ (Operations Research, OR)の 手法が使われることが多い。これは，復旧過程とその 影響を定量化し，例えば復旧時間の短縮を図るために, 過程を最適化する手法である. OR の手法は社会シミュ レーションにおいて多用され，近年，数理的に高度な 手法も開発されている ${ }^{21)}$. 地震工学の分野でも最適の 解を探索する解法も研究22),23),24),25)され, 地震に特有 の不確実性を考慮した解法 ${ }^{26)}$ も提案されている。しか し OR の手法では, 復旧過程と影響を陽な形で定式化 することが必要となるため, 社会の構成員・組織の多 様性を表現するには限界がある。この点を補うシミュ レーションが MAS であると考えられている27)。一方， KISS (Keep It Simple and Stupid) 原理 ${ }^{8)}$ が示すよう に, MAS のエージェントは単純である. 高度なエージェ ントを構築しても妥当性を検証することが難しいから である。このため，定量的なシミュレーションには OR の手法，定性的なシミュレーションのはMAS，という 使い分けがされてきたと著者らは判断している.

\section{3. 復旧過程の定式化}

本研究の最終目標はライフラインの最適な復旧戦略 の選択である。なお，復旧戦略とは技術者をライフラ インの被害個所に配置する仕方，最適とは使用者の便 益が最も早く回復することを意味する。この目標達成 の第一段階として, 本論文では「技術者が被害個所に 
配置されると，修復作業によって使用者の便益が回復 する」として復旧過程を定式化する．本論文ではこの 数理問題問題を資材配分問題 29$), 30), 31), 32)$ と称する.

\section{(1) 修復}

ライフラインの修復作業は，大きく調査・設計・施工 に区別される. 各作業に必要な各種資材の量として被 害を定量化する。すなわち,

$$
\mathbf{W}_{a}=\{\text { 第 } a \text { 番目の作業に必要な資材 }\}
$$

というべクトルである。ここで下添字 $a$ は 1 から 3 の 值をとり，それぞれ調査・設計・施工を意味する.

ある修復作業に関する技術者の能力を 1 日に投入で きる資材の量として定義し，これを修復速度 $\mathbf{s}_{a}$ とする. この修復作業に第 $p-1$ 日までに投入された資材の量を $\mathbf{w}_{a}^{(p-1)}$ とすると, これは次のように更新される.

$$
\mathbf{w}_{a}^{(p)}=\mathbf{w}_{a}^{(p-1)}+\mathbf{s}_{a} \times 1 .
$$

ここで×の後の 1 は 1 日を意味する. $\mathbf{w}_{a}<\mathbf{W}_{a}$ であ れば作業継続， $\mathbf{w}_{a}=\mathbf{W}_{a}$ であれば作業終了となる。 な お， ベクトルの不等号は全成分に同じ不等号が成立寸 ることを意味する。作業は順番に行われ並行しない，す なわち第 $a-1$ 番目の作業が終了してから第 $a$ 番目の 作業が開始する.

本論文では被害と損傷を区別する．大・中・小破から 無被害に対応させて, 損傷 $d$ を 3 から 0 までの整数と し, 第 3 番目の作業である施工に応じて $d$ が決まるこ とを仮定する。すなわち，

$$
d=F\left(\mathbf{w}_{3}^{(p)}\right) \text {. }
$$

本論文では関数 $F$ を次のように設定する.

$$
F\left(\mathbf{w}_{3}^{(p)}\right)=N \quad \text { if } r_{N}^{W} \mathbf{W}_{3} \geq \mathbf{w}_{3}^{(p)}>r_{N+1}^{W} \mathbf{W}_{3}
$$

ここで $r_{i}^{W}$ は $\mathbf{W}_{3}$ を割り引く係数であり, $r_{0}^{W} \geq \cdots \geq$ $r_{4}^{W}$ を満たす. また $r_{0}^{W}$ と $r_{4}^{W}$ の值はそれぞれ 1 と 0 で ある. 他の $r_{N}^{W}$ の值は適宜設定する. また式の if は等 号が成立するための条件を明示している.

損傷が低下寸るに従って，ライフラインを利用でき る量は増えていく. 利用可能量 $c$ を損傷 $d$ の関数とす る.すなわち，

$$
c=G(d) .
$$

本論文ではライフラインの本来の利用可能量 $C$ を使っ て関数 $G$ を次のように設定する.

$$
G(d)=r_{N}^{D} C \text { if } d=N .
$$

ここで $r_{0}^{D} \geq \cdots \geq r_{3}^{D}$ である. $r_{0}^{D}=1$ であるが，他の $r_{N}^{D}$ の值は適宜設定する.

\section{(2) 利用}

ライフラインの利用方法は様々であるため, 本論文 では，1)一つの使用者は複数の活動を持つこと，2) 活
土木学会論文集A1 (構造・地震工学), Vol. 67, No. 1, 165-176, 2011.

動は 1 つないし複数のライフラインを使うことを仮定 する.さらに，3) 各活動から利用量に応じた便益を得 ることを仮定する.

上記の仮定に基づき，使用者がある活動で使うライ フラインの利用量を

$$
\mathbf{u}=\{\text { ライフラインの利用量 }\}
$$

というべクトルで表し，使用者が得る便益 $b$ を

$$
b=H(\mathbf{u})
$$

とする．常時の便益 $B$ と利用量 $\mathbf{U}$ を使って，本論文で は関数 $H$ を次のように設定する.

$$
H(\mathbf{u})=r_{N}^{B} B \quad \text { if } r_{N-1}^{U} \mathbf{U} \leq \mathbf{u}<r_{N}^{U} \mathbf{U}
$$

ここで $r_{1}^{B} \leq \cdots \leq r_{3}^{B}$ と $r_{0}^{U} \leq \cdots \leq r_{3}^{U}$ である. $r_{3}^{B}=$ $r_{3}^{U}=1$ であり, 他の $r_{N}^{B}$ と $r_{N}^{U}$ の值は適宜設定する.

利用量 $\mathbf{u}$ の成分は対応するライフラインの利用量で ある.したがって全使用者の利用量の総和は, このライ フラインの利用可能量 $c$ を超えることができない. す なわち，利用量には次の制約がある.

$$
c>\sum \mathbf{u} \text { の対応する成分. }
$$

この制約を満たすよう, 利用者に利用量を割り振るに はさまざまな方法が考えられる，本論文では，簡単の ため, 先にライフラインを使う使用者が必要量を使う という「早い者勝ち」の原則を採用する.

\section{(3) 資材配分問題}

定式化された修復と利用を用いて資材配分問題を設 定する. 初期の設定として, 第 $\alpha$ 番目のライフライン に対し, 利用可能量を $C^{\alpha}$, 第 $i$ 番目の部材の被害を $\mathbf{W}_{a}^{\alpha i}$ とする. 地震発生後の第 $p$ 日目を考える. この被 害に第 $m$ 番目の技術者が配置される場合, 前日までに $\mathbf{w}_{a}^{\alpha i(p-1)}$ であった資材投入量は, 式 (2) に示すように 次式で更新される.

$$
\mathbf{w}_{a}^{\alpha i(p)}=\mathbf{w}_{a}^{\alpha i(p-1)}+\mathbf{s}_{a}^{m} \times 1 .
$$

更新された $\mathbf{w}_{a}^{\alpha i p}$ から第 $\alpha$ 番目のライフラインの損傷 $d^{\alpha}$ が次式で計算される.

$$
d^{\alpha}=\max _{i} F^{\alpha i}\left(\mathbf{w}_{3}^{\alpha i(p)}\right) .
$$

式 (4) に示すように, $F^{\alpha i}$ は第 $\alpha$ 番目のライフライン の第 $i$ 番目の部材の損傷を与える関数である. この $d^{\alpha}$ より利用可能量が次式で計算される.

$$
c^{\alpha}=G^{\alpha}\left(d^{\alpha}\right) .
$$

式(6)に示すように, $G^{\alpha}$ は第 $\alpha$ 番目のライフラインの 利用可能量を与える関数である.

第 $n$ 番目の使用者が第 $k$ 番目の活動にしたがって $\mathbf{u}^{n k}$ の利用をする場合, この使用者の便益 $b^{n}$ は次式で計算 される。

$$
b^{n}=\sum_{k} H^{n k}\left(\mathbf{u}^{n k}\right)
$$


式 (9) に示すように, $H^{n k}$ は第 $n$ 番目の使用者の第 $k$ 番目の活動がもたらす便益を与える関数である. 使用 者の利用量には次の制限が付く.

$$
c^{\alpha}>\sum_{n, k}\left(\mathbf{u}^{n k}\right)_{\alpha^{\prime}}
$$

ここで下添字 $\alpha^{\prime}$ は第 $\alpha$ 番目のライフラインの利用に対 応する成分を意味する.

式 (14) の $b^{n}$ の和が第 $p$ 日目の全便益 $b(p)$ となる. 「どの修復速度を持つ技術者を何日目にどの被害に配 置するか」という配分を決めると，それに応じて全便 益の時系列 $\{b(1), b(2), \cdots\}$ が計算される. したがって, 例えば, $\sum_{p} b(p)$ を最大にする配分として, 資材配分 問題を設定することができる，なお， $b(p)$ の代わりに 式 (12)の $d^{\alpha}$ の和である $d(p)$ を使って全損傷の時系列 $\{d(1), d(2), \cdots\}$ を計算し, 例えば $\sum_{p} d(p)$ を最小にす る配分を考える問題も考えられる。しかし本論文では この問題は扱わない.

\section{（4）数値解析手法としのて MAS}

式の形式は単純であるものの, 設定された資材配分 問題を解くことは難しい。これには二つの理由が挙げ られる. 第一に $F^{\alpha i}, G^{\alpha} や H^{n k}$ 等が連続関数でなく, $d^{\alpha}, c^{\alpha}$ や $b^{n}$ が離散的に更新されることである.この ため, 例えば, 配置に関する $b(p)$ の変化率を解析的に 計算することは困難となる，第二に，対象とする地域 が大きい場合，ライフラインや被害箇所，技術者・使 用者の数が多くなる. 変数の数が増える他, $\mathbf{w}_{a}^{\alpha i(p)}$ や $\mathbf{u}^{n k}$ といったベクトルの成分も様々となり, 多様な変数 とその関数を扱わなければならなくなる.

資材配分問題は離散的な関数や变数を多数使う最適 問題である.さまざまなライフラインや技術者・使用 者を考慮しなければならない場合, 最適解を求める以 前に，そもそも，修復と利用を計算することすら難し い. MAS は, この離散的な関数や変数をエージェント の機能やデータとして設定することで修復と利用を計 算する. また，オブジェクト指向プログラミングを活 用することで，ライフラインや技術者・使用者の多様 性に対応することも可能となる.

MAS を使って修復と利用が計算できるようになって も, 最適な配置を見つけることは難しい. 最適配置の代 替として,「いくつかの配分を設定し, 各々の配分から 計算される $b(p)$ を比較することで, 最も適当な配分を 選ぶ」という問題を設定する. 本論文では，これも資材 配分問題と位置づける. 配分を復旧戦略と称し, 被害 個所を修復する順番として設定する，具体的には，第 $\alpha$ 番目のライフラインの第 $i$ 番目の損傷に $I^{\alpha i}$ という ID を付け, 復旧戦略を次の ID の列として定義するの
である。

$$
S=\left\{I^{\alpha i}, I^{\alpha^{\prime} i^{\prime}}, I^{\alpha^{\prime \prime} i^{\prime \prime}}, \cdots\right\}
$$

復旧戦略 $S$ に応じて技術者が配置される。なお, 技術 者の配置は「早い者勝ち」の原則に従うことにする.す なわち, あらかじめ技術者に ID を振り, この ID の順 に $S$ の被害個所へ技術者が配置されるのである.

1 つのライフラインには複数の部材があるため, 同じ ライフラインの被害個所を $S$ の中で均等に置くと, ラ イフラインは一様に修復されることになる. 本論文で はこれを一様復旧の戦略と称する。 また, ライフライ ンを利用する使用者の便益の和としてそのライフライ ンの便益の最大值を算定し，この最大值の大きいライ フラインの被害個所を $S$ の最初に置くと, 便益の最大 值が大きいライフラインが優先的に修復される。 これ を便益最大の戦略と称する。

\section{MAS の設計}

開発された復旧過程の MAS を, エンバイロンメント とエージェントに分けて説明する. C++を使い, エン バイロンメントとエージェントに独自のクラスを設計 する. 設計項目はクラスのデータとメンバ関数である. 多様性を高めるため, 抽象クラスを継承して具体的な クラスを設計するというオブジェクト指向プログラミ ングの標準的な方針を採る。

\section{(1) エンバイロンメント}

\section{a) ライフライン}

図-2 に示寸ように, ライフラインの抽象クラスは Structure である.このクラスの主要なデータは部材 の抽象クラス StructureMember, 主要なメンバ関数は 損傷と利用可能量を与える damage() と $\operatorname{capacity}()$ である. StructureMember は, 部材の形状のデータ の他, 程度や位置のデータを持つ被害の抽象クラス StructureDamage を持つ.

具体的なクラスとして埋設管に対応した LifeLine を設計する.このクラスの部材は管と継手に対応する Pipe と Junction, 被害はこの部材の亀裂と引き抜け に対応する Crack と Cutoff とする.もう一つの具体的 なクラスとして道路に対応した RoadStructure を設計 する.このクラスの部材は路面に対応する Pavement, 被害は変形に対応するDeformation とする.

既往研究34)を参考に, GIS を使った Structure のモ デルの自動構築を行う.自動構築では，1)さまざまな GIS のデータを共通のデータ Network に変換, 2) こ の Network を LifeLine ないし RoadStructure に変 換, という 2 段階の変換を経る. 埋設管の GIS は dxf 形式のファイル, 道路の GIS は $\mathrm{shp} \cdot \mathrm{shx} \cdot \mathrm{dbf}$ 形式の 


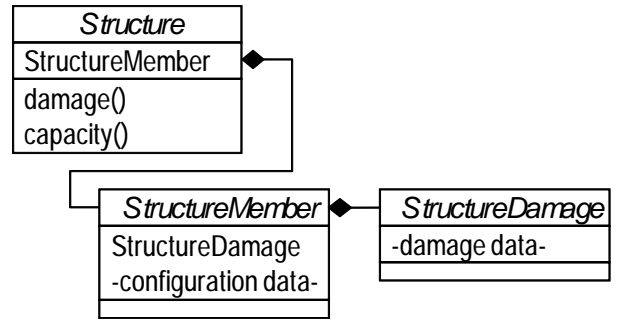

a) 抽象クラス

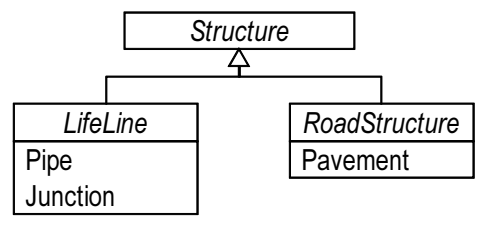

b) 継承されたクラス

図-2 Structure のクラス構造

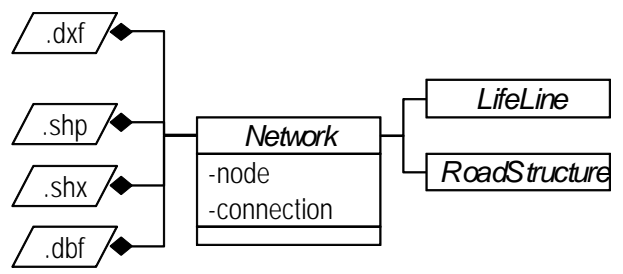

図-3 CMD を使ったライフラインのモデルの自動構築

3 つのファイルが使われるため, このファイルを分析 し，ライフラインをネットワークとみた場合の節点と 連結のデータを抽出してNetworkに変換する (図-3 参 照). すなわち Network は節点と連結のデータを持つ クラスである. LifeLineへの変換では, Network の連 結がPipeの形状に, Network の節点が Junction の位 置となる. RoadStructure 一の変換では, Network の 連結が Pavement の形状となる. dxf 形式の GIS から LifeLine 一の自動変換の例を図-4に示す. 元の GIS にあるネットワークの形状は自動変換された LifeLine のネットワークの形状と細部まで一致している．自動 変換が成功していることがわかる.

地震動が与えられた場合, 部材の損傷の位置と程度 は, 耐震設計・照査に準拠した応答計算によって評価 することができる．簡便な代替として，フラジリティ カーブと乱数を使って損傷の位置と程度を与えること もできる. 次章の数值実験では, 簡単のため後者の方 法を使う。

\section{b) リソース}

被害は修復に必要な資材として定量化されている. エ ンバイロンメントの一つとしてこの資材の抽象クラス Resource を導入する (図-5 参照)。このクラスは資材
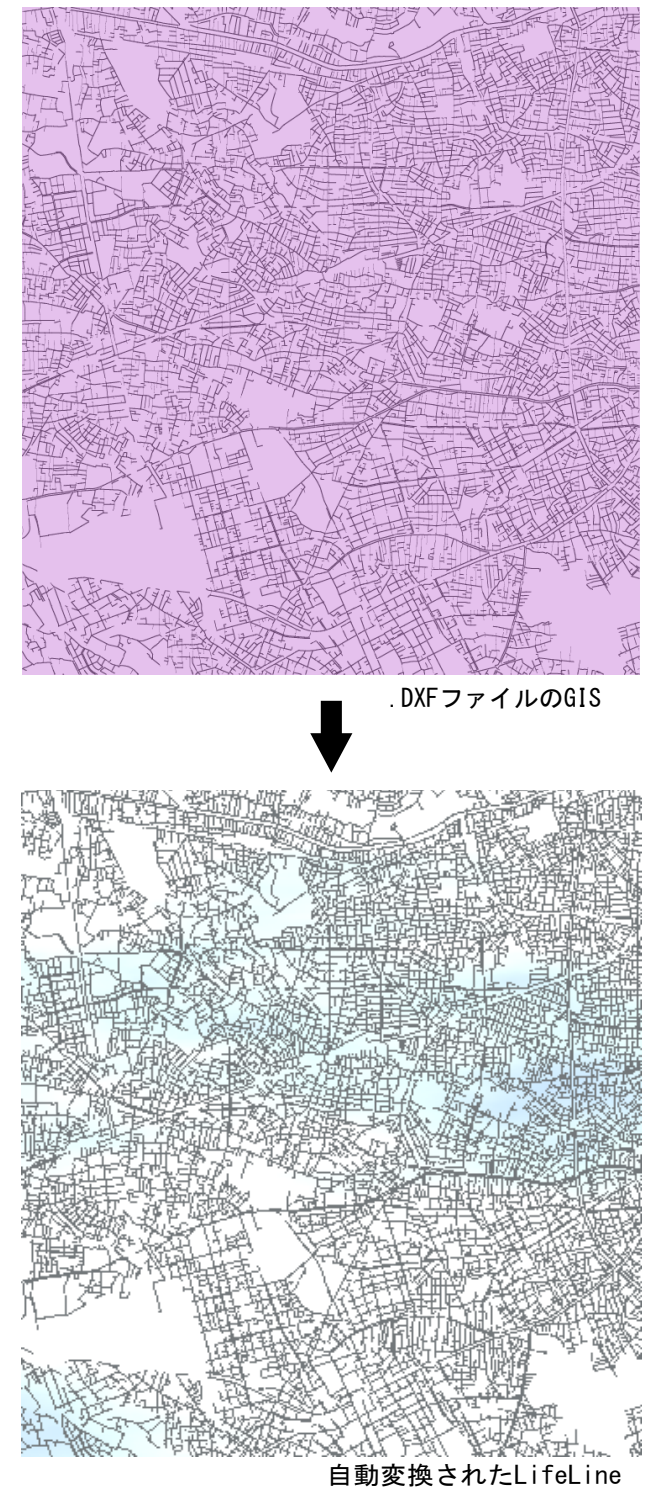

図-4 自動変換の例 (LifeLine)

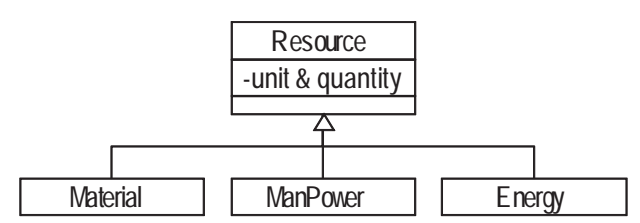

図-5 Resource のクラス構造

の単位と量をデータとする．単位をデータとして持つ ことで，異なる種類の資材の加減や比較の演算が誤っ て行われないようにしている.

具体的なクラスとして, 材料, 人力, エネルギーに 対応した, Material, ManPower, Energy を設計する. 各々のクラスは, コンクリート・鋼材, 労働者・保安作 業員, 電力等, 具体的な対象のデータとなり, 被害・資 材投入量・修復速度の成分となる. 


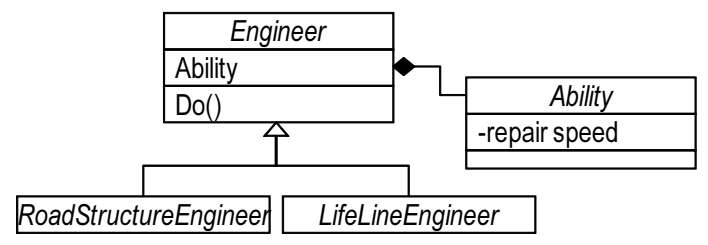

図-6 Engineer のクラス構造

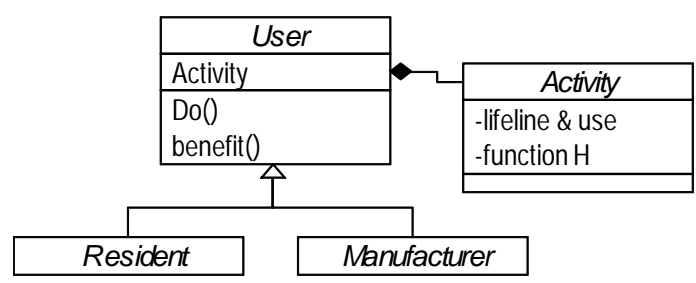

図-7 User のクラス構造

(2) エージェント

\section{a) 技術者}

修復作業は, 損傷の程度の他, 投入できる資材に応 じて変化する．このため，修復を行う技術者のエージェ ントは, KISS 原理 ${ }^{8)}$ に抵触するものの，ある程度複雑 に設計する.

技術者エージェントの抽象クラスを Engineer とす る (図-6 参照). Engineer の主要なデータとメンバ関 数はAbility とDo()である. Ability は調査・設計・ 施工の修復速度のデータ, Do（）はこの 3 つの作業を順 に行う。

具体的なクラスとして，埋設管を修復する技術者に 対応するLifeLineEngineer と，道路を修復する技術 者に対応する RoadStructureEngineer を設計する. LifeLineEngineer の修復速度は Crackないし Cutoff という被害に対応し，Do（）で行う調查・設計・施工 は, 被害検知・埋設管の復旧仕椂の決定・埋設管の修 復工事とする. RoadStructureEngineer の修復速度は Deformation に対応し, Do()の調査・設計・施工は目 視・変形の補修仕様の決定・変形の補修作業である.

\section{b) 使用者}

技術者エージェントに比べて使用者エージェントは 単純である，図-7に示すように，使用者エージェント の抽象クラスUserの主要なデータはActivity, メン バ関数はDo()とbenefit()である.Activityは, 利 用するライフラインとその利用量, 利用量と便益の関 数といった活動のデータである.Do() は個々の活動を 実行し, benefit() を使って全活動の便益を計算する.

具体的なクラスとして，住民に対応した Resident と 工場に対応した Manufacturer を設計する. Resident の活動は， 1 つの LifeLine を利用する生活利用と
土木学会論文集A1 (構造·地震工学), Vol. 67, No. 1, 165-176, 2011.

複数の RoadStructure を利用する通勤通学である. Manufacturer の活動は 1 つの LifeLine を大量に利 用する生産である。

\section{(3) オブジェクト指向プログラミング}

いかなる技術者・使用者エージェントであれ，その 機能は「固有の修復速度でのライフラインの修復」と 「固有の活動に応じたライフラインの利用」に要約でき る. Engineer とUserの主要メンバー関数であるDo() がこの修復と利用を行う。どちらも抽象クラスの仮想 関数であり，具体的な内容は個々の具体的なクラスで 定義される.

技術者・使用者エージェントが対象とする部材とラ イフラインはスーパークラスとなる抽象クラスのポイ ンタで指定する. 寸なわち, Engineer が修復を行う被 害はStructureDamage のポインタ, UserのActivity ではStructure のポインタが使われる.

抽象クラスの仮想関数とポインタを使うことで拡張 性を高めることができる，実際，開発された MAS で は, Engineer とUser のポインタが仮想関数Do()を 使って修復・利用を行う (補 $\mathrm{A}$ 参照)。この結果, エー ジェントやライフラインの新規のクラスを MAS に導入 しても, コードの拡張はポインタの指定を変えるだけ ですむ.

\section{MAS の性能検証}

本章では, 開発された復旧過程の MAS の妥当性と 潜在的な有効性を検証する数值実験を行う. 妥当性の 検証では小規模な復旧過程の問題を設定し, 解析解と MAS の解を比較する. 有効性の検証では, 復旧過程に 関係する要因を変えた数值実験を行う.

\section{(1) 数值実験の設定}

資材配分問題の初期条件として, Structure の被 害, Engineer の修復速度, User の活動のデータを 設定する.PipeLine の被害である Crack と Cutoff, RoadStructure の被害である Deformation に関し， 調查・設計・施工をそれぞれ $1 \cdot 2 \cdot 3$ として，必要な Resourceの量を表-1a) に整理する. 修復速度は被害に 対応するため, LifeLieEngineer の Crack とCutoff, RoadStructure $の$ Deformation $の$ 修復速度を表-1b) に整理する. Resident の活動である日常生活と通勤通 学, Manufacturer の活動である生産において, 利用す るライフラインと常時の利用量・便益を表-1c) に整理 する.

式 (4) と式 (6) の関数 $F$ と $G$ は Structure のメン バ関数 damage() と $\operatorname{capacity}()$, 式 (9) の関数 $H$ は 
表-1 パラメータの設定

a) 被害

\begin{tabular}{|c|c|c|c|c|c|}
\hline & \multicolumn{3}{|c|}{ Resource } \\
\hline & & & Material & ManPower & Energy \\
\hline \multirow{6}{*}{ PipeLine } & & 1 & - & 1 & - \\
\hline & Crack & 2 & - & 1 & - \\
\hline & & 3 & 10 & 5 & 2 \\
\hline & & 1 & - & 1 & - \\
\hline & Cutoff & 2 & - & 1 & - \\
\hline & & 3 & 5 & 3 & 1 \\
\hline \multirow{3}{*}{ RoadStructure } & & 1 & - & 1 & - \\
\hline & Deformation & 2 & - & 2 & - \\
\hline & & 3 & 200 & 100 & 20 \\
\hline
\end{tabular}

b) Ability

\begin{tabular}{|c|c|c|c|c|c|}
\hline & \multicolumn{3}{|c|}{ Resource } \\
\hline & & & Material & ManPower & Energy \\
\hline \multirow{6}{*}{$\begin{array}{l}\text { PipeLine } \\
\text {-Engineer }\end{array}$} & & 1 & - & \begin{tabular}{|l|}
1 \\
\end{tabular} & - \\
\hline & Crack & 2 & - & 1 & - \\
\hline & & 3 & 10 & 5 & 2 \\
\hline & & 1 & - & 1 & - \\
\hline & Cutoff & 2 & - & 1 & - \\
\hline & & 3 & 5 & 3 & 1 \\
\hline \multirow{3}{*}{$\begin{array}{l}\text { RoadStructure } \\
\text {-Engineer }\end{array}$} & & 1 & - & 1 & - \\
\hline & Deformation & 2 & - & 1 & - \\
\hline & & 3 & 20 & 20 & 2 \\
\hline
\end{tabular}

c) Activity

\begin{tabular}{|l|c|c|c|c|}
\hline \multicolumn{2}{|c|}{} & Structure & 利用量 & 便益 \\
\hline \multirow{2}{*}{ Resident } & 日常生活 & LifeLine & 1 & 50 \\
& 通勤通学 & RoadStructure & 1 & 25 \\
\hline Manufacturer & 生産 & LifeLine & 10 & 250 \\
\hline
\end{tabular}

Userのメンバ関数 benefit() となる. 関数 $F$ には $r_{N}^{W}$, 関数 $G$ には $r_{N}^{D}$, そして関数 $H$ には $r_{N}^{C}$ と $r_{N}^{U}$ の值を設 定しなければならない. 設定された值を表-2に示す.

\section{（2）妥当性の検証}

第 2 章で示した資材配分問題は小規模な復旧過 程では解析的に解くことが可能である.小規模な 問題として, PipeLine と RoadStructure を各々 1 つ, PipeLineEngineer と RoadStructureEngineer を各々 $1 つ$ ，そしてResident と Manufacturer を各々1 つ用いる (図-8 参照). 簡単のためPipeLine の被害は Crackのみとし，第 1 日目から LifeLineEngineer は Crackに, RoadStructureEngineer は Deformation に配置するという戦略を考える。

MAS の数值解と解析解の比較の例として, PipeLine とRoadStructure の損傷の回復と, Residentと Manufacturer の便益の和の日変化を図-9 に示す. 数 值解は解析解と一致している. 表-1 のパラメータを変 えても, 数值解は解析解と一致する. 小規模な問題の 正解を出すことは必要条件でしかないが，修復と利用 の数值解析手法としての, 開発された MAS の妥当性が 示されている.
表 -2 関数の係数

a) 関数 $F\left(r^{G}\right)$

\begin{tabular}{|c|c|c|c|}
\hline \multirow{2}{*}{ damage } & \multicolumn{2}{|c|}{ LifeLine } & RoadStructure \\
\cline { 2 - 4 } & Pipe & Junction & Pavement \\
\hline 3 & 0.0 & 0.0 & 0.0 \\
2 & 0.0 & 0.0 & 0.2 \\
1 & 0.0 & 0.0 & 0.5 \\
0 & 1.0 & 1.0 & 1.0 \\
\hline
\end{tabular}

b) 関数 $G\left(r^{D}\right)$

\begin{tabular}{|c|c|c|}
\hline damage & LifeLine & RoadStructure \\
\hline 3 & 0.0 & 0.0 \\
2 & 0.0 & 0.2 \\
1 & 0.0 & 0.5 \\
0 & 1.0 & 1.0 \\
\hline
\end{tabular}

c) 関数 $\mathrm{H} \mathrm{G}\left(\mathrm{r}^{\mathrm{U}}, \mathrm{r}^{\mathrm{B}}\right)$

\begin{tabular}{|c|c|c|c|c|c|c|}
\hline \multirow{2}{*}{} & \multicolumn{3}{|c|}{ Resident } & \multicolumn{2}{c|}{ Manufacturer } \\
\cline { 2 - 7 } & \multicolumn{2}{|c|}{ RoadStructure } & \multicolumn{2}{c|}{ LifeLine } & \multicolumn{2}{c|}{ LifeLine } \\
\cline { 2 - 7 } & $\mathrm{r}^{\mathrm{U}}$ & $\mathrm{r}^{\mathrm{B}}$ & $\mathrm{r}^{\mathrm{U}}$ & $\mathrm{r}^{\mathrm{B}}$ & $\mathrm{r}^{\mathrm{U}}$ & $\mathrm{r}^{\mathrm{B}}$ \\
\hline 3 & 1.0 & 1.0 & 1.0 & 1.0 & 1.0 & 1.0 \\
2 & 0.9 & 0.9 & 0.9 & 0.9 & 0.7 & 0.7 \\
1 & 0.5 & 0.5 & 0.5 & 0.5 & 0.3 & 0.3 \\
0 & - & 0.0 & - & 0.0 & - & 0.0 \\
\hline
\end{tabular}

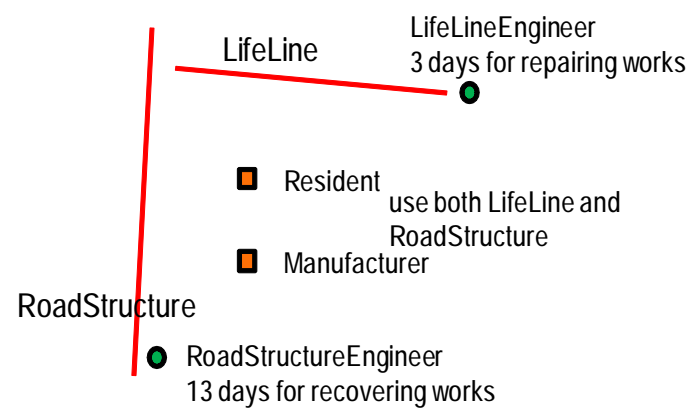

図-8 妥当性の検証に使われた問題

\section{（3）有効性の検証}

修復に関係する要因は，被害の規模・領域の広さ・技 術者数の 3 点である. この 3 つの要因に表-3 に示す大 小 2 つの值を設定し, 数值実験を行った。この表には 使用者数も記載している. 簡単のため LifeLine のみ をエンバイロンメントとし, 実際の GIS データからモ デルを構築する。領域の広さは GIS データで指定され た区画の数である．損傷と便益は

$$
\{d, b\}=\left\{\sum d^{\alpha}, \sum b^{n}\right\}
$$

として計算する. 復旧戦略は第 3 章で説明された一様 復旧と便益最大とし, 記号 $s_{1}$ と $s_{2}$ で表す.

被害の規模は, ライフラインの単位長さ毎に被害が起 こる確率として設定されている. 被害の規模が大きいこ とは地震動が大きいことを意味する. 最初にLifeLine 


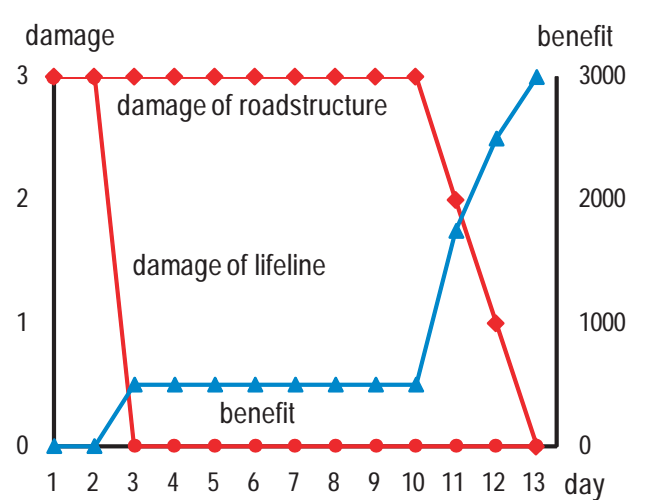

a) MAS の数值解

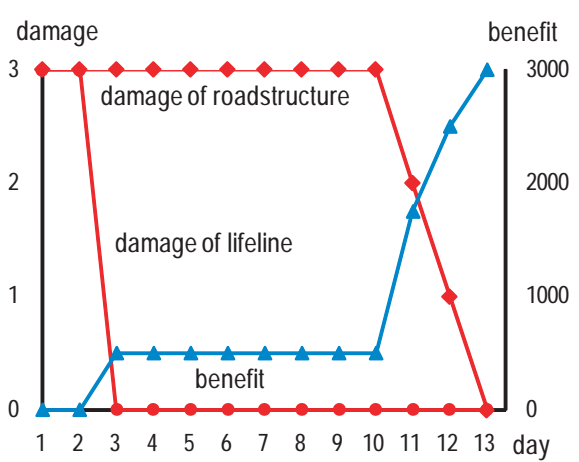

b) 解析解

図 -9 小規模な資材配分問題
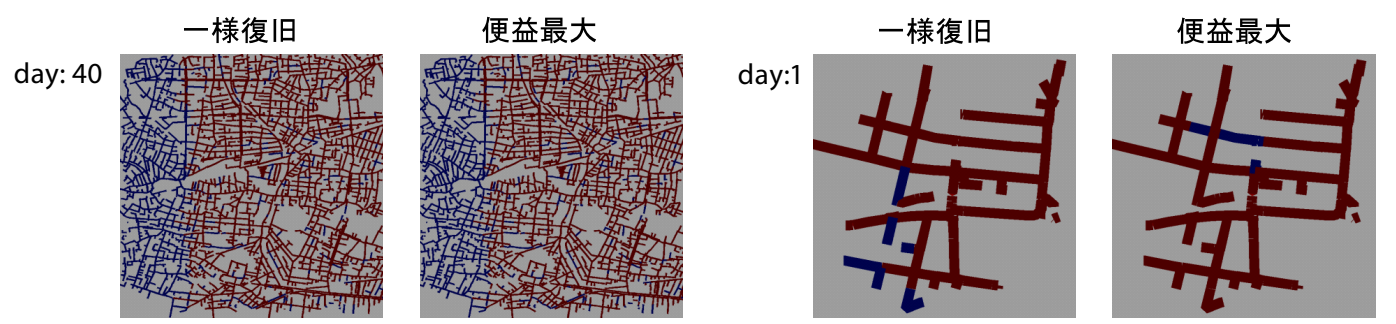

day:85

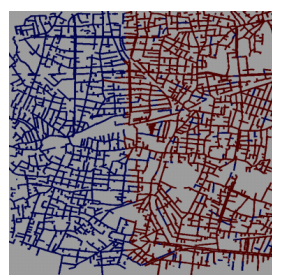

day:130

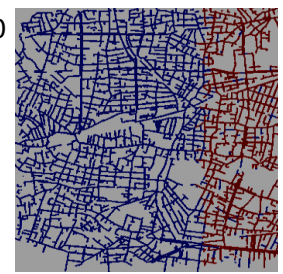

day:163
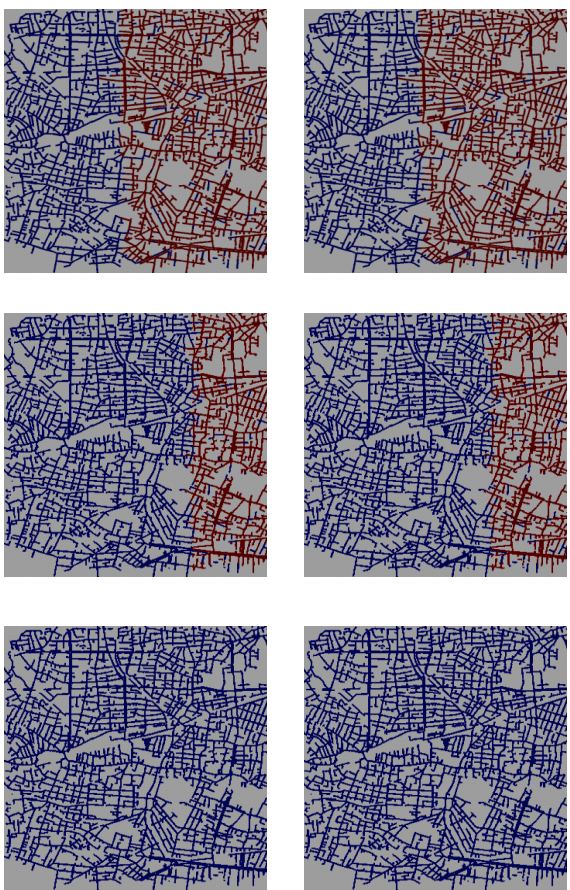

a) 大局的 day:2

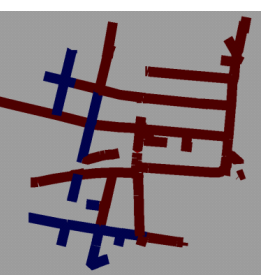

day:3
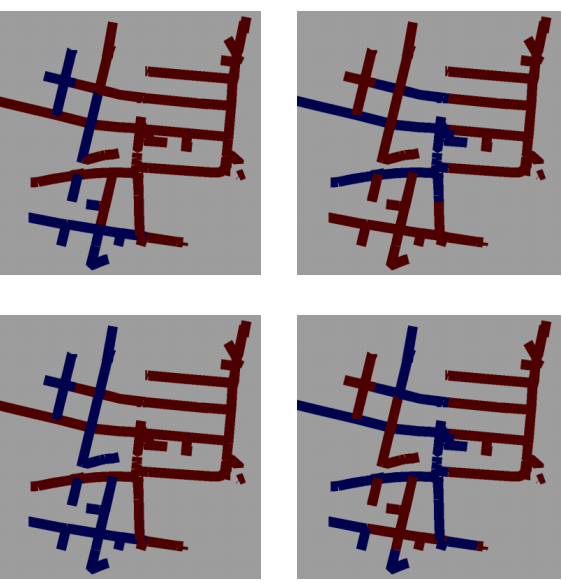

day:4
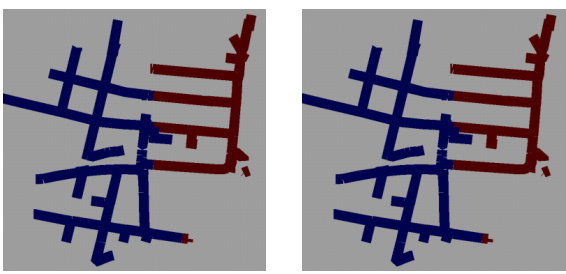

— 被害個所有

被害個所無 （被害修復済）

b) 局所的

図-10 ライフラインの修復の様子

の部材であるPipe の長さにこの被害の規模をかけて Crackの数を計算し, 次に乱数を使ってランダムに位 置を設定する. Junctionの Cutoff もランダムに設定 する。

LifeLine の被害と利用可能量, LifeLineEngineer の修復速度, Resident とManufacturer の活動に適当
なばらつきを与える。一様確率に従う乱数を使い，個々の 被害, 修復速度, 活動の值に対して表-1 の值に $\pm 10 \%$ の 幅で変動を与える.またResidentとManufacturer の 位置を乱数で指定し, 最寄りの LifeLineを使うように 設定する。この結果, LifeLineを利用する Resident とManufacturer の数に偏りが生じる. 


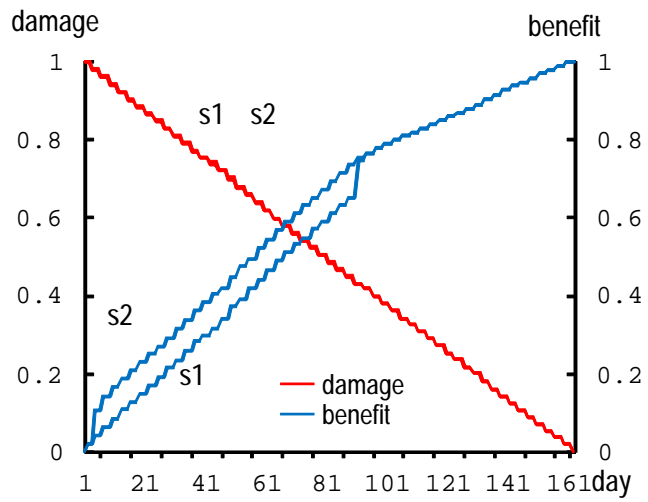

a) 技術者数：小

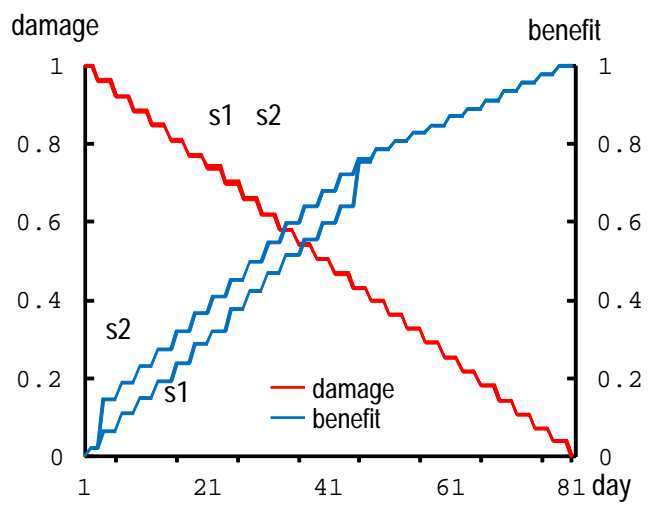

b) 技術者数 : 大

図-11 被害の規模・領域の広さ:大

表-3 設定されたパラメータ

\begin{tabular}{|l|c|c|}
\hline & small & large \\
\hline damage ratio & 0.2 & 0.5 \\
block number & 25 & 400 \\
engineer number & 30 & 50 \\
\hline resident number & \multicolumn{2}{|c|}{1,000} \\
manufacturer number & \multicolumn{2}{|c|}{200} \\
\hline
\end{tabular}

MAS の例として，被害の規模・領域の広さ・技術者 数が大の場合において，被害を受けたライフラインが 修復されている様子を図-10に示す。赤が被害を受け た状態，青が修復された状態である。大局的には戦略 による修復の差は明瞭ではないが, 局所的には戦略に よって修復されるLifeLine の順番が異なることがわ かる.

最初に被害の規模・領域の広さが大の場合の数值実験 を行う. 技術者数を大と小とした場合, 復旧戦略 $s_{1}$ な いし $s_{2}$ に従って計算された $d$ の低下と $b$ の回復の日変 化を図-11 に示す. 図の $d$ と $b$ は最大值で除して無次 元化されている. 技術者数が大と小のどちらの場合で も $d$ の低下は復旧戦略の違いの影響を受けない. しか し, $b$ の回復は $s_{2}$ のほうが早い. 復旧過程の初期に大き い便益を持つライフラインを優先して修理するという,

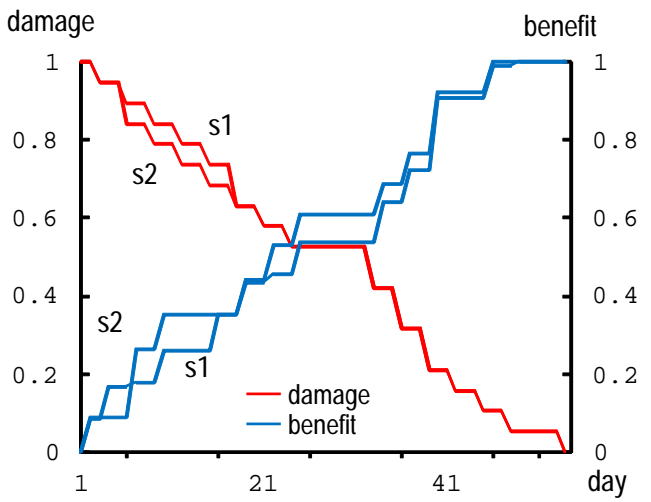

a) 技術者数：小

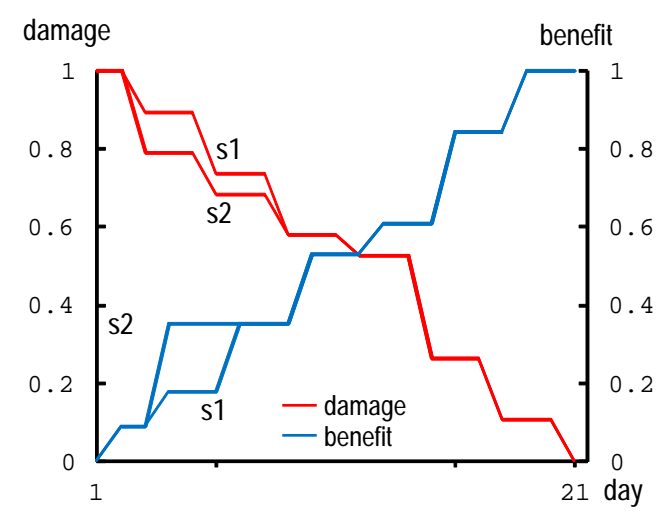

b) 技術者数 : 大

図-12 被害の規模・領域の広さ：小

便益最大の戦略の当然の結果である。しかし， $s_{1}$ から $s_{2}$ に復旧戦略を変えると，技術者数によらず，復旧の 前半約 $50 \%$ の間, $b$ の回復が $10 \%$ 程度大きくなるとい う定量的な結果は MAS を使って得られるものである.

次に被害の規模・領域の広さが小の場合に対し, MAS によって計算された $d$ と $b$ の日変化を図-12 に示す．技 術者数が大と小の両方の場合で， $s_{2}$ に従う方が $d$ の低 下と $b$ の回復が早いことがわかる．dの低下は，技術者 の大小に関わらず $s_{2}$ の方が常に早い. しかし $b$ の回復 は複雑である. 技術者数が大の場合は $s_{2}$ の方が常に $b$ の回復を早めるが，技術者数が小の場合は，復旧 4 日 目では $s_{1}$ の方が $b$ の回復を $10 \%$ 早めている。この逆転 は $s_{2}$ は便益の大きさだけに着目してライフラインを選 択し, 被害に必要な日数の選定をしないために起こる と考えられる。

上記の数值実験より, $d$ の低減と $b$ の回復の日変化は, 被害の規模・領域の広さ・技術者数の組み合わせに複 雑に依存することがわかる. 被害に比べて相対的に技 術者が少ない場合, 復旧戦略の違いが $b$ の回復により 大きな影響を与える傾向がある。この傾向を確認する ため, 表-4 に示す技術者の数・被害の規模・領域の広 さを使った数值実験を行った. MASによって計算され た $d$ と $b$ の日変化を図-13 に示す. 技術者数が小の場 
表-4 被害に比べて技術者が少ない場合のパラメータ

\begin{tabular}{|l|r|c|}
\hline & small & large \\
\hline engineer number & 30 & 50 \\
\hline block number & \multicolumn{2}{|c|}{200} \\
engineer number & \multicolumn{2}{|c|}{30} \\
resident number & 1,000 \\
manufacturer number & \multicolumn{2}{|c|}{200} \\
\hline
\end{tabular}

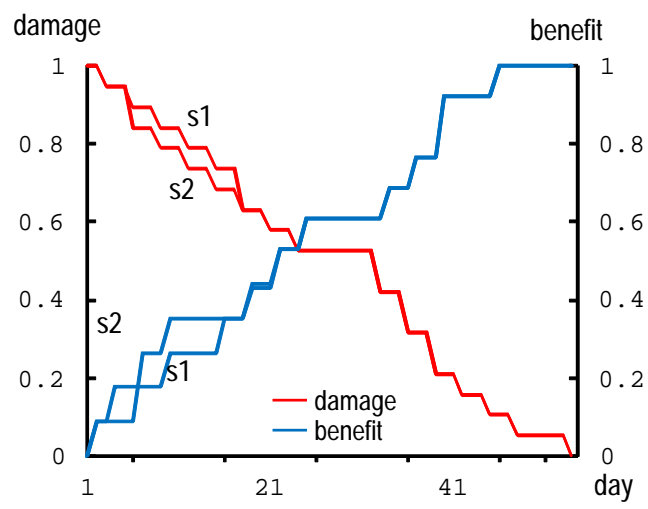

a) 技術者数 : 小

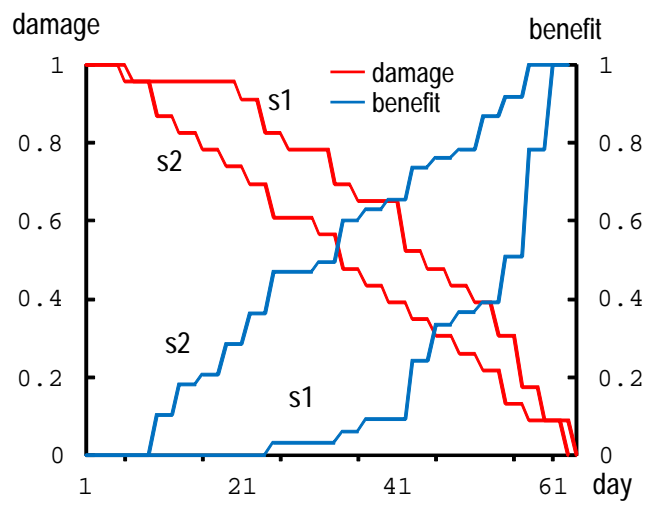

b) 技術者数 : 大

図-13 被害に比べて技術者が少ない場合

合， $s_{2}$ に従うことで $d$ の低下と $b$ の回復が顕著に変わ ることがわかる，定量的には， $d$ の低下と $b$ の回復の開 始が約 15 日も早まり, 20 日目前後では $b$ の回復は最大 $40 \%$ 程度大きくなる。

\section{MAS の高度化の方針}

本論文で開発された MAS では，基盤となる抽象クラ スは設計されたものの，具体的なクラスの数は少ない. 使用者の便益を計算する機能は含まれたものの, 異種 のライフラインの技術者の協調は取り入れられていな い. 復旧戦略立案の支援という目的には，より多様な ライフラインや技術者を組み込む等, MAS の高度化が 必要である.

ライフラインの相互依存性を考慮することは，効果
土木学会論文集A1 (構造·地震工学), Vol. 67, No. 1, 165-176, 2011.

的な復旧戦略の立案に重要である。利用に関しては相 互依存性が加味されている。 これは, 複数のライフラ インを使うUserの活動では, 必要なライフラインが全 て復旧して始めて利用が再開されるためである. 修復 に関しては, 被害個所近くに損傷した RoadStructure があると Engineer の修復速度を低下させることで, 修 復に相互依存性を加えることもできる，モデルの構築 は容易ではなく, また, その妥当性の検討も不可欠で あるが, MAS の高度化として, 適切な相互依存性のモ デルを修復と利用に組み込むことは検討しなければら ない.

MAS には各ライフラインに利用可能量があるという 制約が設けられているが，技術者が利用する資材の総 和に供給可能量という制約を設けることもできる. 復 旧初期ではこの制約が損傷の低下や便益の回復に与え る影響は大きい。供給可能量は, 該当地域の資材の備 蓄量や他地域からの運搬量の他, 交通ネットワークの 回復にも依存する.MAS の高度化として，この点も考 慮した資材の供給可能量の合理的な設定を検討する必 要がある.

Engineer に比べUser の機能は簡単である。しかし， User はライフラインの顧客のモデルであるため, 本来 は顧客情報を利用して使用するライフラインや使用量 の正確なデータを MAS に取り込む必要がある. 高度化 にはこれも必要である. なお MAS は数值解析手法で ある．顧客情報から得られるデータはあくまでも入力 データであり，MAS の開発に不可欠な情報ではない.

\section{7. おわりに}

本論文では，ライフラインの復旧過程の MAS の開発 を行った。この MAS は, 技術者が各種資材を構造物部 材の被害箇所に投入していくという資材配分問題とし て復旧過程を定式化され, 復旧に応じて使用者がライ フラインの利用を再開し便益を得るというシミュレー ションである. 与えられた復旧戦略に従って, 技術者 の修復と使用者の利用が計算される. 数值実験の結果, 開発された MAS は，概衫納得できる結果を出力してお り, 開発された MAS の潜在的な有効性が示唆される.

復旧作業管理者のヒアリングに基づいて MAS は設計 されているものの, 異なるライフラインの復旧作業の 協調を図ることができる程度に MAS の信頼性を上げ ることが必要である.このためにも MAS の高度化は不 可欠である. 同様に, 各種ライフラインに適用できる 汎用性を確保するためにも, MAS の高度化は不可欠で ある。また大都市を対象とすると，大規模並列計算も 必要となる. さらに, 復旧戦略の最適化には, 資材配 分問題を解くMAS を使って最適戦略を見出寸計算が必 


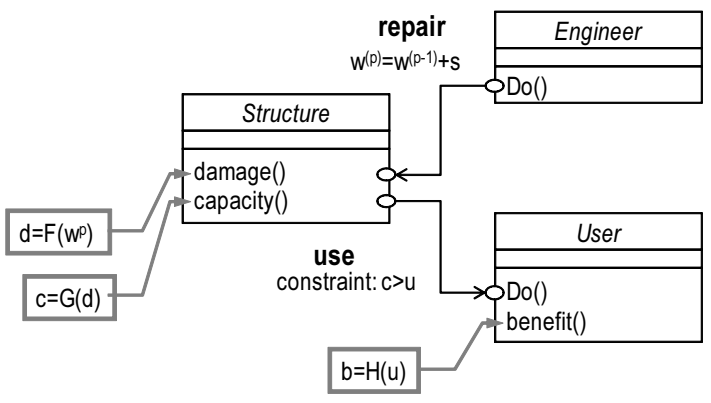

a) Engineer とUser を使う修復と利用の計算手順

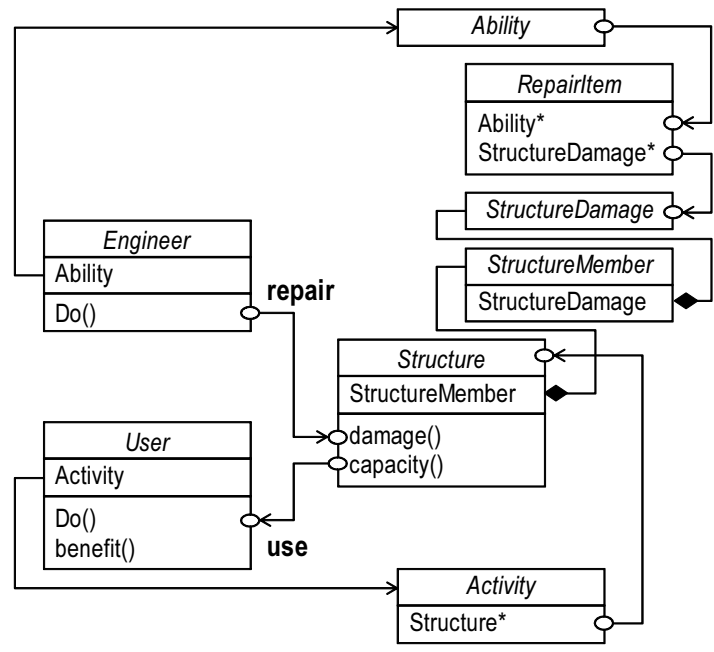

b) Structure からみた修復と利用

図-14 MAS のアルゴリズム

要となり，計算規模は大規模化する。この点も軽視は できない.

謝辞 LifeLine と LifeEngineer の設計に際し，株式 会社東京ガスより貴重な情報の提供を受けた。ここに 記して感謝の意を表する。

\section{付録 I MAS のアルゴリズム}

資材配置問題を解く数值解析手法としての MAS のア ルゴリズムは，Structureに着目すると図-14a)とし て整理できる.すなおち，被害が与えられた Structure は, EngineerのDo() によって修復, UserのDo()に よって利用可能量の制限の下で利用される。修復は資 材投入量の更新, 修復による損傷と利用可能量は式 (4) の関数 $F$ と式 (6) の関数 $G$, 便益は式 (9) の関数 $H$ に よって計算される.

一方，修復と利用を計算する実際のアルゴリズム は，図-14b) に示すように，Engineer とUser を主 体とするほうが容易である。 Engineer の Do(）が修 復, User の Do() が利用をすると, ポインタで結ばれ た StructureDamage やStructure を通じて，資材投 入量の更新の他，損傷・利用可能量・便益が計算される. なお図-14b) に示された RepairItem は，ポインタを 介して Engineer を StructureDamageに関連付けるク ラスである。関連付けは式 (16) の復旧戦略 $S$ に従う.

\section{参考文献}

1）磯山龍二, 片山恒雄: 大規模水道システムの地震時信頼度 評価法，土木学会論文報告集，321 号，pp. 37-45，1982.

2) 星谷勝, 大野春雄 : 震災時ライフラインの相互影響を
考慮した復旧過程の機能評価法, 土木学会論文集, No. 386/I-8, pp. 387-396, 1987.

3) 佐藤忠信, 一井康二 : 遺伝的アルゴリズムを用いたライ フライン網の最適復旧過程に関する研究, 土木学会論文 集，No.537/I-35，pp. 245-256， 1996.

4) 山崎文雄 : リアルタイム地震防災システムの現状と展望, 土木学会論文集, No. 577/I-41, pp. 1-16, 1997.

5) 亀田弘行, 能島暢呂: 第 8 章 相互関連, ライフライン 施設の被害と復旧 阪神・淡路大震災調查報告, 土木学 会阪神・淡路大震災調査報告編集委員会，1997.

6) American Lifelines Alliance: Power Systems, Water, Transportation and Communications Lifelines Interdependencies. http://www.cimap.vt.edu/ 2DOC/ ALA Lifeline Report Final Draft 030606.pdf, 2006.

7) 東京ガス株式会社 HP, http://www.tokyo-gas.co.jp.

8) 山影進, 服部正太 (編集)：コンピュータのなかの人工社 会一マルチェージェントシミュレーションモデルと複雑 系, 構造計画研究所, 2002.

9) 北中英明: 複雑系マーケティング入門—マルチエージェン ト・シミュレーションによるマーケティング, 2005.

10）塩沢由典, 松井啓之, 谷口和久, 中島義裕, 小山友介: 人工 市場で学ぶマーケットメカニズム-U-Mart 経済学編 (知 的エージェントで見る社会)，共立出版，2006.

11）梶谷義雄，多々納祐一，山野紀彦，朱牟田善治 : 製造業 を対象としたライフライン途絶抵抗係数の推定, 自然災 害科学, 2005 .

12）梶谷義雄，多々納祐一，山野紀彦，朱牟田善治：非製造 業を対象としたライフライン途絶抵抗係数の推定, 自然 災害科学，2005.

13) 白谷啓行, 能島暢呂, 杉戸真太, 佐藤慶昇 : 供給系ライ フラインの地震時機能停止が製造業に与える影響の評価 モデル, 第 12 回日本地震工学シンポジウム, 2006 .

14）土屋哲，多々納祐一，岡田憲夫 : 地震災害時のライフラ イン途絶が及ぼす経済被害の計量化に関する研究, 地域 安全学会論文集, 2008 .

15) 豊田安由美, 庄司学: ライフライン事業者が想定する地 震時応急復旧活動のシナリオ分析とその相互依存関係 首都直下地震を想定した場合の事例分析一, 地域安全学 会論文集，2008.

16）杉本博之, 片桐章憲, 田村亨, Lu, B. : GA によるライフ ライン系被災ネットワークの復旧プロセス支援に関する 
研究, 構造工学論文集, Vol. 43A, pp. 517-524, 1997.

17) 佐賀井重雄, 朱牟田善治: 災害時の配電設備の応急復旧 過程シミュレータの開発, 第 1 回地震リスクマネジメン トと事業継続性シンポジウム, 2009.

18）鹿島建設株式会社 : 地震による上水道管路の被害予測と 復旧戦略を事前検討できるシステム， 2006.

19) McDaniels, T., Chang, S., Peterson, K., Mikawoz, J., and Reed, D.: Empirical framework for characterizing infrastructure failure interdependencies, Journal of Infrastructure Systems, Vol. 13, No. 3, pp. 175-184, 2007.

20) Berke, P.R., Song, Y. and Stevens, M.: Integrating hazard mitigation into new urban and conventional developments. Journal of Planning Education and Research, Vol. 28, No. 4, pp. 441-455, 2009.

21) 久保幹雄 : ロジスティクス工学, 朝倉書店, 2001.

22) Chang, S. E., Svekla, W. D., and Shinozuka, M.: Linking Infrastructure and Urban Economy: Simulation of Water Disruption Impacts in Earthquakes, Environment and Planning, B, Vol. 29, No. 2, pp. 281-301, 2002.

23) Liu, B., 斉藤和夫, 栘谷有三 : 震災道路網における復 旧計画に関する研究, 都市学研究, Vol. 40, pp. 28-46, 2003.

24) Bruneau, M., Chang, S. E., Eguchi, R. T., Lee, G. C., O'Rourke, T.D., Reinhorn, A. M., Shinozuka, M., Tierney, K., Wallace, W. A. and von Winterfeldt, D.: A framework to quantitatively assess and enhance the seismic resilience of communities, Earthquake Spectra, Vol. 19, No. 4, pp. 733-752, 2003.

25）森本孝紀, 徳丸正孝, 村中得明, 今西茂: 被災道路復旧 計画問題の一解法, 情報処理学会研究報告, Vol. 2005, No. 20, pp. 45-48, 2005.

26) 古田均, 中津功一朗, 野村 泰稔: 不確実性を考慮した被
災ネットワーク復旧計画策定に関する研究, 土木学会論 文集 A, Vol. 64, No. 2, pp. 434-445， 2008.

27）味方さやか，小林一郎：ライフライン網の相互連関を考 慮した災害復旧計画作成への取り組み, 2010 年度人工 知能学会全国大会 (第 24 回) 論文集, 2D2-4, pp. 1-3, 2010.

28) Peiris, T.P.: Proposal of multi-agent simulation for recovery process in urban area damaged by an earthquake, Master Thesis Dissertation, Department of Civil Engineering, the University of Tokyo, 2008.

29) Ibaraki, T. and Katoh, N.: Resource Allocation Problems: Algorithmic Approaches, MIT Press, 1988.

30) Kurt, M. and Bretthauer, B. S.: A pegging algorithm for the nonlinear resource allocation problem, Computers and Operations Research, Vol. 29, No. 5, pp. 505-527, 2002.

31) Shioura, A.: Fast scaling algorithms for M-convex function minimization with application to the resource allocation problem, Discrete Applied Mathematics, Vol. 134, No. 1-3, pp. 303-316, 2004.

32) Yin, P.-Y. and Wang, J.-Y.: Optimal multipleobjective resource allocation using hybrid particle swarm optimization and adaptive resource bounds technique, Journal of Computational and Applied Mathematics, Vol. 216, No. 1, pp. 73-86, 2008.

33) 弓削田恭兵, 堀宗朗, 市村強, Wijarthne, L. : ライフラ イン地震被害に対する復旧過程のマルチエージェントシ ミュレーションの開発, 応用力学論文集, Vol. 13, 2010.

34) 堀宗朗, 田中謙吾, S. Gholamreza, 市村強, 小国健二: 自然災害シミュレーションのための GIS から都市モデル への汎用的データ変換, 土木学会論文集 A, Vol. 66, No. 1, pp. 1-12, 2010.

(2010.7.2 受付)

\title{
ON DEVELOPMENT OF MULTI-AGENT SIMULATION FOR RECOVERY PROCESS OF LIFELINE DAMAGED BY EARTHQUAKE
}

\author{
Muneo HORI, Kyohei YUGETA, Tsuyoshi ICHIMURA and Lalith WIJARTHNE
}

In the view of recovery planning for lifelines damaged by earthquake, this paper seeks to develop a multiagent simulation (MAS) for recovery process of lifelines. The process is formulated as a discrete resource allocation problem, and an MAS is used as a numerical method to solve it. The MAS takes advantage of object oriented programming, being capable of handling various kinds of lifelines as well as their engineers and users. Automatic model construction is studied. The validity of the MAS is verified by solving simple problems, and the potential usefulness is discussed. 